\title{
QUALITY OF RUBBER HOSPITAL SHEETING
}

\author{
By. Herminiwati, Arum Yuniari
}

\begin{abstract}
13 (thirteen) samples of Rubber hospital sheeting of various trademark which were taken from manufacturers and markets in Bandung, Yogyakarta and Surabaya, had been tested for the purpose of this research. Quality of rubber hospital sheeting is determined by factors that onsure either the strength or wear, by testing them in accordance with test method as described in ASTM.

It could be found from the test results that : the thickness was 0,406 $0,506 \mathrm{~mm}$, breaking strength $54,47-77,85 \mathrm{~kg} / \mathrm{cm} 2$, elongation at break $99,8 \%-147,8 \%$.

The rubber hospital sheeting was also subjected to hydrostatic water resistance test and no leakage was accured.

It had good steam sterikization, accelerated Aging, phenol and alcohol resistance as well.

\section{INTISARI}

Dalam penelitian ın telah diuji 13 sampel perlak karet untuk rumah sakit dari berbagai merk yang diambil langsung dari pabrik maupun pasaran didaerah Bandung, DI Yogyakarta dan Surabaya.

Mutu perlak karet untuk rumah sakit ditentukan berdasarkan pada faktorfaktor yang menjamin segi kekuatan bahan maupun segi penggunaannya, dengan metode pengujian menurut ASTM. Dari hasil pengujian diperoleh hasil sebagai berikut tebal $0.406-0,506 \mathrm{~mm}$, tegangan putus 54.47 $77,85 \mathrm{~kg} / \mathrm{cr} 2$. perpanjangan putus $99,8-147,8 \%$. Perlak karet yang diuji tidak tembus air dalam pengujian hydrostatic water resistance. juga mempunyai ketahanan terhadap sterilisasi uap. ketahanan terhadap pengusangan. ketahanan terhadap ketahanan terhadap alkohol yang baik.
\end{abstract}

\section{PENELITIAN MUTU PERLAK KARET UNTUK RUMAH SAKIT}

\section{PENDAHULUAN}

Perlak karet merupakan salah satu barang keperluan rumah sakit yang penting karena diperlukan sebagai alas untuk tidur para penderita sakit dan penutup kasur pada tempat-tempat tidur di rumah sakit 
Didalam penggunaannya perlak karet haruslah sering kali dicuci, dibersihkan dan dibebaskan dari berbagai macam bekas kotoran dan bibit penyakit. Oleh karena itu perlak karet untuk rumah sakit haruslah mempunyai kualitas yang baik, tidak mudah rusak dan tahan terhadap perlakuan yang dikenakan terhadapnya.

Perlak karet telah banyak diproduksi dan dijumpai dipasaran dalam berbagai merk, namun belum ada standar mutu maupun persyaratan yang dapat menjamin fungsi dan penggunaannya. Maka perlu kiranya dilakukan penelitian terhadap mutu perlak karet untuk keperluan rumah sakit sebagai dasar penyusunan standar mutunya.

\section{TINJAUAN PUSTAKA}

Perlak karet untuk rumah sakit merupakan lembaran karet yang tipis, tanpa lapisan kain, dengan tebal antara $0,5-1 \mathrm{~mm}$ serta mempunyai permukaan yang halus rata.

Perlak karet dibuat dari kompon karet alam, karet sintetik atau campurannya. Kompon digiling melalui silinder-silinder mesin calender hingga berbentuk lembaran tipis panjang. Dengan melalui bolt conveyer, lembaran yang mempunyai panjang $\pm 50 \mathrm{~m}$ dengan dialasi kain digulung dalam suatu rol untuk selanjutnya divulkanisasi dengan udara panas pada suhu $120^{\circ} \mathrm{C}$ dan tekanan sekitar $3,5 \mathrm{~kg} / \mathrm{cm} 2$.

Lembaran dapat dibuat dalam berbagai warna dan dapat dipotong dengan panjang sesuai dengan kebutuhan.

Adapun mutu perlak karet untuk rumah sakit menurut ASTM D 3738 78 didasarkan pada faktor-faktor yang menjamin segi kekuatan bahan maupun segi penggunaannya, yang meliputi : tebal, tegangan putus, perjanjangan putus, ketahanan terhadap pengusangan, ketahanan tembus air, ketahanan terhadap sterilisasi uap, ketahanan terhadap phenol dan ketahanan terhadap alkohol.

Guna menjamin segi penggunaannya, maka ketentuan persyaratan untuk ketahanan terhadap phenol dan alkohol adalah tidak boleh menjadi lekatlekat, melunak, mengeras, melepuh dan mengelupas.

Untuk ketahanan terhadap sterilisasi uap dipersyaratkan sebagai tidak boleh menjadi kaku, rapuh, lekat-lekat dan retak-retak. Sedangkan ketahanan tembus air dipersyaratkan sebagai tidak tembus air.

Secara organoleptis perlak karet juga harus mempunyai kenampakan yang baik, berbau normal, tidak sobek, berlubang, terpotong, kotor dan bernoda serta tidak mengeluntung dibagian tepinya.

\section{METODE PENELITIAN}

\section{Bahan dan peralatan}

\subsection{Bahan}

- 13 sampel perlak karet dari berbagai merk yang diambil langsung dari pabrik maupun pasaran didaerah Bandung, DI Yogyakarta dan Surabaya.

- Phenol $5 \%$

- Alkohol $70 \%$

- Kertas saring

\subsection{Peralatan}

- Alat uji tegangan putus (tensile strength tester).

- Alat ukur tebal (mikrometer) dengan ketelitian 0,02 mm.

- Alat uji ketahanan tembus air

- Autoclave

- Oven

- Kotak gelas

- Penjepit

\section{Prosedur penelitian}

Sebelum dilakukan pengujian, contoh uji terlebih dulu dilakukan pengamatan secara organoleptis terhadap keadaan dan kenampakan selanjutnya contoh uji dikondisikan dalam ruangan yang mempunyai suhu 27 $\pm 2^{\circ} \mathrm{C}$ dan kelembaban relatif $65 \pm 5 \%$ selama minimal 16 jam. Pengujian perlak karet meliputi :

\subsection{Tebal}

Pengujian dilakukan dengan mikrometer yang mempunyai ketelitian $0,02 \mathrm{~mm}$.

Pengukuran tebal contoh dilakukan pada tiga titik diberbagai tempat yang berbeda dan hasilnya dirata-rata.

\subsection{Tegangan putus dan perpanjangan putus}

Pengujian dilakukan dengan alat uji tensile strength. Potong cuplikan dengan bentuk dan ukuran sebagai berikut : 


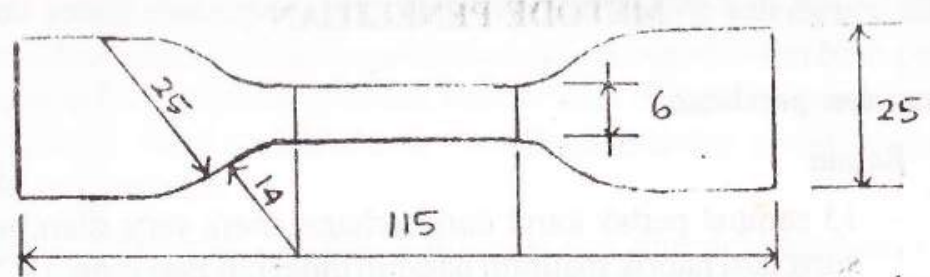

Gambar : Bentuk dan ukuran cuplikan tegangan putus dan perpanjangan putus.

Jepi t cupli kan pada alat dan lakukan penarikan dengan kecepatan $500 \mathrm{~mm} /$ menit sampaikan cuplikan putus.

Catat beban maksimum yang diperlukan untuk menarik cuplikan sampai putus dan catat pula perpanjangan putusnya.

2.3. Ketahanan tembus air (hydrostatio water resistance)

Potong cuplikan dengan ukuran $30 \mathrm{~cm} \times 30 \mathrm{~cm}$, jepit cuplikan pada bingkai penjepit.

Semprotkan air dengan alat penyemprot yang bertekanan $25 \pm 2$ psi selama 5 menit.

Lakukan penyemprotan secara tegak lurus dengan jarak antara 10

$15 \mathrm{Cm}$ dari permukaan cuplikan.

Pada akhir pengujian amati ada tidaknya kebocoran pada daerah yang diuji.

2.4. Ketahanan terhadap sterilisasi uap

Potong cuplikan berbentuk segi empat dengan ukuran $30 \mathrm{~cm} \times$ $30 \mathrm{~cm}$, lipat cuplikan hingga menjadi empat persegi panjang berukuran $30 \mathrm{~cm} \times 15 \mathrm{~cm}$. Kemudian lipat sekali lagi sehingga berbentuk segi empat berukuran $15 \mathrm{~cm} \times 15 \mathrm{~cm}$.

Masukkan kedalam alat sterilisasi uap dengan suhu $125 \pm 2^{\circ} \mathrm{C}$ selama $20 \pm 0,5$ menit dihitung dari saat tercapainya suhu tersebut. Ambil cuplikan dari dalam alat dan didinginkan pada suhu kamar selama 20 menit. Ulangi siklus pemanasan dan pendinginan tersebut hingga 5 kali.

Pada akhir pengujian amati ada tidaknya kerusakan yang berupa : kekakuan, kerapuhan, kelekatan, keretakan dan perubahan warna.

2.5. Ketahanan terhadap pengusangan (accolorated aging)

Potong cuplikan dengan ukuran $20 \mathrm{~cm} \times 10 \mathrm{~cm}$.

Masukan cuplikan kedalam oven dengan sirkulasi udara pada suhu $70 \pm 1^{\circ} \mathrm{C}$ selama 7 hari.

Keluarkan cuplikan dan amati ada tidaknya kerusakan yang berupa kekakuan, kerapuhan, këlekatan dan perubahan warna.

\subsection{Ketahanan terhadap phenol}

Potong cuplikan berbentuk segi empat dengan sisi $15 \mathrm{~cm}$. Cuci cuplikan memakai sabun dan air, kemudian bilas dan keringkan, dengan lap atau kertas saring.

Siapkan larutan $5 \%$ phenol - aquadest dan rendam cuplikan didalam larutan tersebut selama $166 \pm 1$ jam. Kotak perendam harus cukup besar agar cuplikan cukup terendam dan ditutup rapat untuk menghindari penguapan.

Setelah perendaman ambil cuplikan, bilas dengan air dan keringkan dengan kertas saring. Diamkan selama 2 jam, selanjutnya amati cuplikan terhadap ada tidaknya kerusakan yang ditandai dengan pelunakan, pengerasan, lekat-lekat, lepuh dan pengelupasan.

\subsection{Ketahanan terhadap alkohol}

Potong cuplikan berbentuk segi empat dengan sisi $15 \mathrm{~cm}$. Cuci cuplikan dengan sabun dan air, kemudian bilas dan keringkan dengan lap atau kertas saring.

Tempatkan dalam kotak gelas yang berisi $70 \%$ alkohol - aquadest, biarkan selama $22 \pm 0,25$ jam. Tutup kotak gelas rapat-rapat untuk menghindari penguapan.

Pada akhir perendaman, ambil cuplikan bilas dengan air dan keringkan dengan kertas kering.

Lakukan pengamatan terhadap adanya kerusakan yang berupa pelunakan, Pengerasan, lekat-lekat, lepuh dan pengelupasan. 


\section{HASIL PENELITIAN DAN PEMBAHASAN}

\section{a. Hasil-hasil penelitian seperti tertera dalam tabel}

Tabel : Hasil pengujian perlak karet untuk rumah sakit (rata-rata dari 3 kali ulangan )

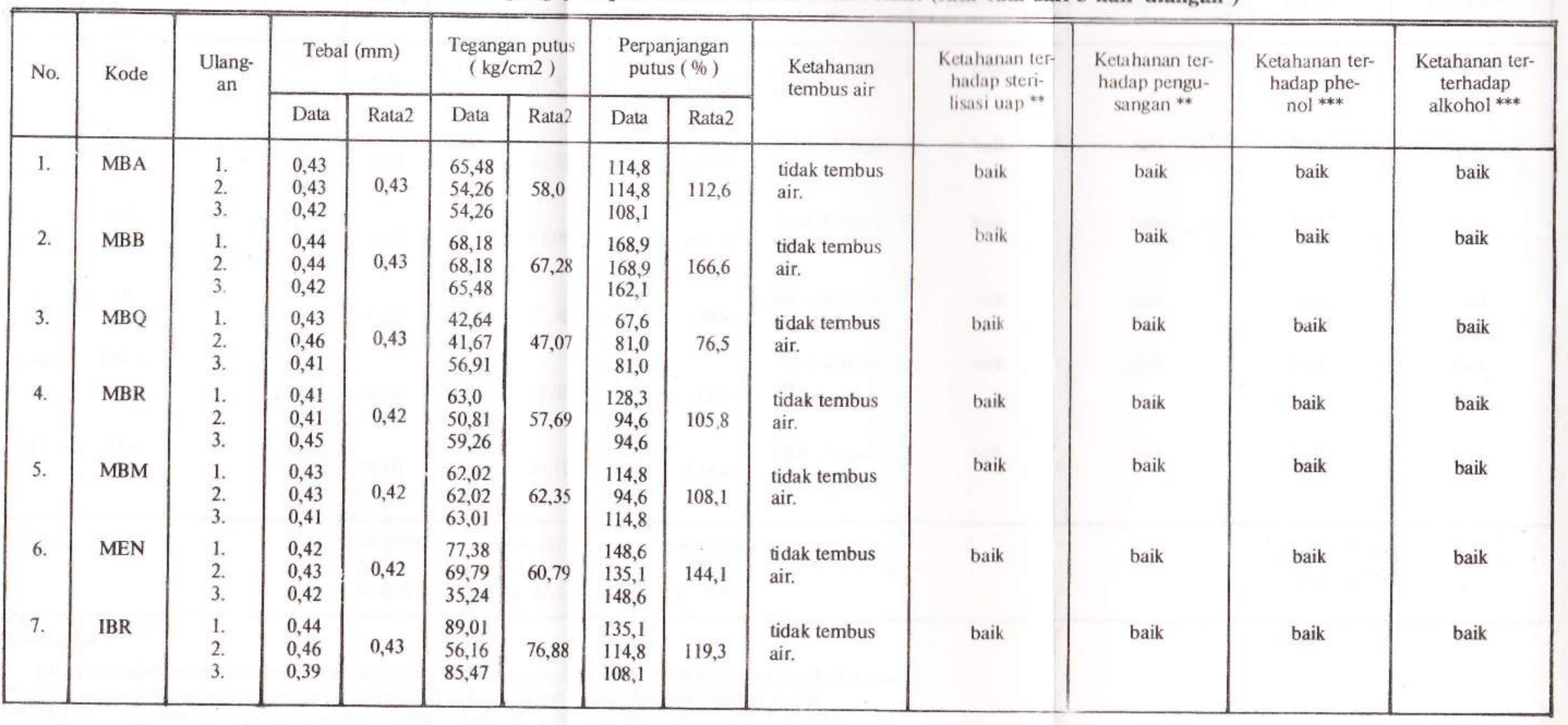




\section{b. Pembahasan :}

1. Ditinjau dari tebal, maka perlak karet yang diproduksi umumnya relatif tipis. Menurut Maurya G.P, tebal perlak karet untuk rumah sakit antara 0,5-1 mm. Dengan ketentuan tersebut hanya $15 \%$ sampel yang diuji memenuhi tebal minimal $0,50 \mathrm{~mm}$. Namun bila ditinjau dari nilai tegangan putus dan perpanjangan putus ternyata sampel yang lebih tebal tidak selalu mempunyai nilai yang lebih tinggi. Hal ini dapat disebabkan oleh beberapa hal seperti tingkat kualitas bahan baku dan bahan pembantu yang dipakai dalam pembuatan kompon karet, penambahan filler atau bahan pengisi serta kondisi proses.

Tegangan putus dan perpanjangan putus merupakan faktor penting yang mencerminkan kekuatan dan tingkat mutu bahan. Nilai tenganan putus dan perpanjangan putus bervariasi antara $57,47-77,85 \mathrm{~kg}$ / cm2 dan $99,8-147,8 \%$.

Oleh karena itu dengan nilai tegangan putus dan perpanjangan putus yang tinggi dan tebal yang memenuhi persyaratan akan lebih menjamin kualitasnya.

2. Disamping harus mempunyai sifat-sifat fisika yang baik, maka perlak karet untuk rumah sakit juga harus mempunyai ketahanan terhadap perlakuan-perlakuan yang selalu dikenakan maupun bahan-bahan yang kontak langsung dengan perlak karet tersebut.

Dari hasil pengujian dengan larutan phenol $5 \%$ dan alkohol $70 \%$ menunjukkan hasil yang baik, dimana perlak karet tidak menunjukkan tanda-tanda kerusakan seperti lekat-lekat, melunak, mengeras, melepuh dan mengelupas.

Phenol maupun alkohol merupakan disinfektan dan agensia germicide yang efektif, dimana daya bunuh terhadap mikroorganisme disebabkan karena mudahnya penetrasi agensia tersebut kedalam sel mikroorganisme sehingga mengakibatkan presipitasi, koagulasi dan denaturasi protein protoplasma sel.

Oleh karena itu ketahanan perlak karet terhadap bahan disinfektan akan menunjang fungsi dan penggunaannya.

3. Pengujian ketahanan terhadap sterilisasi uap menunjukkan hasil yang baik, dimana perlak karet tidak menunjukkan tanda kerusakan seperti kaku, rapuh, lekat-lekat, retak-retak dan berubah warna.

Untuk pengujian ketahanan tembus air, perlak karet yang diuji tidak menunjukkan tanda kebocoran.

Pencucian dengan penyemprotan air maupun sterilisasi dengan uap panas merupakan cara yang dilakukan untuk membersihkan dan 
membebaskan barang-barang keperluan rumah sakit dari berbagai kotoran dan bibit penyakit.

Perlak karet yang berkualitas rendah dan proses pembuatannya kurang baik akan mudah rusak dalam pengujian ketahanan terhadap sterilisasi dan menunjukkan tanda kebocoran karena sobek atau berlubang dalam pengujian hydrostatic water resistance.

Ketahanan terhadap pengusangan yang baik merupakan petunjuk bahwa perlak karet relatif tahan lama dan tidak cepat mengalami penurunan sifat fisika.

\section{KESIMPULAN}

1. Sifat-sifat fisika perlak karet untuk rumah sakit yang meliputi tebal, tegangan putus dan perpanjangan putus masih bervariasi. Dari hasil analisa data diperoleh nilai tebal $0,406-0,506 \mathrm{~mm}$, tegangan putus 54,47 $77,85 \mathrm{~kg}$ dan perpanjangan putus $99,8-147,8 \%$.

2. Pengujian untuk ketahanan terhadap phenol dan alkohol, sterilisasi dan pengusangan diperoleh hasil yang baik dan memenuhi persyaratan, dedemikian pula untuk ketahanan tembus air, ternyata perlak karet yang diuji tidak menunjukkan tanda-tanda kebocoran atau tembus air.

3. Mutu perlak karet untuk rumah sakit ditentukan berdasarkan faktorfaktor yang menjamin segi kekuatan bahan maupun penggunaannya sehingga diharapkan dapat memenuhi fungsinya.

\section{DAFTAR PUSTAKA}

1. ASTM D $3738-78$

Standard Specification for Rubber - Coated

Cloth Hospital Sheeting

American Society for Testing Materials

2. ASTM D 471 - 79

Test for Rubber property - Tensile properties American Sociaty for Testing Materials

3. S. Herminiwati dkk, BBKKP 1984. Pengujian perlak karet untuk rumah sakit Balai Besar Penelitian dan Pengembangan Industri Barang Kulit, Karet dan Plastik Yogyakarta.

4. Maurya G.P Hospial Sheeting

Rubber Technology and Manufacture

Small Business Publications SBP Building 4/45, Roop Nagar Delhi - 110007

5. Salle A.J.

Fundamental Principles of Bacteriology Fifth Edition

Mc Graw : Hill Book Company, Inc Kogakusha Company, Lid. Tokyo 